\title{
Armenia and Security Issues in the South Caucasus
}

Garnik S. Asatryan ${ }^{1}$

South Caucasus, or Transcaucasia, is a region noted for its instability, in both strategic and ethno-political as well as cultural aspects. Security issues in the region are cross-sectional, not only for the three primary states in the South Caucasus-Azerbaijan, Armenia, and Georgia-but also involve the interests of adjacent countries: Russia on the north; Iran on the south; Turkey, Ukraine, Bulgaria, and Greece on the west; the Central Asian states Turkmenistan, Uzbekistan, Tajikistan, and Kazakhstan on the east. Added to this mix are the interests of the U.S. and the European Union, as well as, of course, China. As a result, the South Caucasus has been rather vulnerable to destabilizing effects from the outside.

A characteristic feature of the entire region is the diversity of ethnicities, cultural traditions, and confessional identities of the population, which can at any time spark conflicts with the potential for developing into larger problems. It is to be noted, however, that the atrophy of the ideal of cultural pluralism in the South Caucasus is mainly traceable to those in political circles who are interested (for various reasons) in destabilizing the regional situation. The putative state of constant conflict in the South Caucasus is actually a rather illusory phenomenon. Despite the many cultural, ethnic, religious, linguistic, and other cleavages in the region, the South Caucasus has become home to a relatively solid community, integrating the whole variety of regional ethnic groups, both with regard to outlook and psyche as well as to many social categories, such as common social preferences, moral and behavioral standards, etc. What we see here is the establishment of the so-called "Caucasian mentality." Therefore, no underscoring or exaggeration of the things that divide the nations of the South Caucasus-which without doubt do exist—can overshadow their unifying common features. This underlying similarity may result both from a multi-century symbiosis within the same region as well as from a shared bicentenary history within the Russian Empire and later the USSR. Even the languages of the principal nation-states of Transcaucasia, belonging as they do to the different linguistic families-Indo-European, IberoCaucasian, and Turkic - today compose a single Linguistic Union or Sprachbund. As of today, an average resident of Baku, for example, may have more in common with a Georgian or Armenian than with a Turkish Anatolian despite sharing a common language with the latter. At any rate, the so-called "civilization factor," which more often than not is overemphasized by some authors (especially American ones) with regard to the South Caucasus, seems to be quite irrelevant. In the modern world, with all its developments and trends toward globalization,

\footnotetext{
${ }^{1}$ Garnik S. Asatrian is a Professor at Yerevan State University, the Director of the Caucasian Center of Iranian Studies, and the Editor-in-chief of the journal "Iran and Caucasus".
} 
the "civilizing features" have to some degree been losing their validity as they become more widespread, while regional commonalities remain constant.

However, it is self-evident that a common Caucasian mentality, being a superstructure, cannot be a stabilizing factor on its own without proper integration processes, regional cooperation, and other basic constituents. A superstructural factor per se loses its significance and thus cannot be regarded as an agent of actual policy. The importance of regional unities and, of course, of a unifying mentality, was properly realized in the Soviet Union. In the mid-1980s, the Ideological Department of the Central Committee of the Communist Party of the USSR initiated a project on compiling the regional histories of South Caucasus, North Caucasus, the Baltic republics, etc., aimed at generalizing the people's histories and emphasizing their common heritage. However, this idea was doomed to failure by the turmoil of the final years of the Soviet regime.

Thus, the so-called common Caucasian mentality can remain a real factor and can play a conspicuous role in integration processes only given an essentially stable situation. The present-day political situation, characterized by regional and local conflicts, interference of stakeholders, competition for communication projects, etc., forces the ideal of regional unity into the background.

The strategic significance of the South Caucasus is determined first of all by its location. Transcaucasia is oftentimes characterized as a buffer zone between Russia, Turkey, and Iran, while the European Union views it as a bridge between Asia and Europe. No less important, no doubt, are the region's natural resources and communications networks. Those and other factors can frequently result in fierce competition in various spheres of influence, a competition that is further prompted in the present situation by new geopolitical redistributions. It is therefore the case that the political fate of the South Caucasus region is contingent upon the confluence or juxtaposition of international forces rather than upon the will of any individual state.

This relative lack of agency is quite natural for small, newly independent states like those of the South Caucasus, especially against the backdrop of global stakeholders jockeying for position. Paralyzed economic systems, dependence on international financial structures, foreign debt burdens, efforts to join European organizations and meet their requirements, emergent conflicts and the attendant expectations of various conflict-management policies, refugee problems, corruptible policy-makers-all of these factors are more than sufficient to create a high level of dependence on outside players.

The foremost international power affecting the security of the South Caucasus is definitely Russia and its Transcaucasian policies. It was Russia's decision to disregard (or attempt to defuse) the historical, political, and ethno-cultural realities in the region by creating mini-empires (Azerbaijan, Georgia) strategically counterbalanced by potential conflict zones (Abkhazia, South Ossetia, NagornoKarabakh). Moreover, it was the Leninist national policies that have been respon- 
sible for distorting the ethno-historical boundaries of the area. These policies produced the artificial borderline diasporas: in Georgia, the Armenians (in Javakhk, South-West Georgia adjoining Armenia), and the Turkish-speaking population (in Marneuli, South-East Georgia adjoining Armenia and Azerbaijan); in Azerbaijan, the Lezgians (North Azerbaijan adjoining South-East Dagestan), the Avars (Belokany and Zakataly regions), the Talishis (Lenkoran, Zuvand, Astara, and part of Masala regions adjoining Iran).

These borderline diasporas are, no doubt, a constant source of anxiety and potential conflict in any unstable situation. Of course, a phenomenon like the creation of borderline diasporas can also be activated by the great powers. For example, taking into consideration the present-day situation in Georgia, it is in the cards that Russia could try to heighten the separatist tendencies among the Armenian population of Javakhk, which in reality are virtually dormant. Still, the presence of Russian troops in Javakhk is at present a stabilizing factor and a guarantee of security for the Armenian population. It should be taken into account that, unfortunately, the nationalistic circles in Georgia create a basis for similar trends: various provocations in the Armenian inhabited regions, appeals to resettle the Meskhetian Turks in Javakhk in order to disperse the Armenian element, etc. Fortunately, both in Armenia and Javakhk, as well as in the official circles of Georgia, the danger of such inspirations is clearly understood, and the approach to the Javakhk problem, at least at the present stage, can be described as civil and correct.

With regard to Azerbaijan, which was created on the basis of the historical Transcaucasian lands of Arran and Shirvan in 1918 in a politically targeted allusion to the original name of Iran's Northern provinces, it was intended as a shared Armenian-Muslim state as a "joint common union." The existence of such a state provided Russia with the ability to effect single-handed control over the situation in Transcaucasia. The basic elements of today's ethnic confrontation in the region were certainly laid by the Moscow treaty of 1921, which served as a prototype to the Ribbentrop-Molotov pact of 1939.

At any rate, by virtue of certain geopolitical developments, Armenia has today become an important strategic element for Russia in Transcaucasia. This is in no way to imply that this choice has been voluntary, although Armenia, with its Eastern-Christian values and the Russia-tending population (in contrast, for example, to the institutional Rusophobia of Georgia), being a part of the IndoIranian civilization, simultaneously bridging the Muslim and Christian worlds, is the most expedient partner for Russia in the South Caucasus, having furthermore the most combat-ready and highly-trained army in Transcaucasia. An ideal situation for Russia would of course be, as has traditionally been the goal of Russian policy, balanced relations with the three republics. However, the emerging situation has clearly shown Russia to be lacking any solid ground for establishing stable relations with Azerbaijan or, even more so, with Georgia. Those countries' 


\section{THE QUARTERLY JOURNAL}

orientations are unambiguously dissimilar, oftentimes having hostile manifestations towards Russia. The significance of the Armenian factor for Russia and the natural coincidence of both countries' strategic interests were highlighted by the Agreement of August 29, 1997 "On Friendship, Cooperation, and Mutual Assistance between the Russian Federation and the Armenian Republic."

In Armenia, Russia is approached as a primary strategic partner and, to a certain extent, as a guarantor of security. Despite the close military and political relations between the two nations, along with a high level of economic cooperation, due to the years-long blockade of Armenia and its lack of a common border with Russia, the situation there leaves much to be desired. Posing as the second most important international power player for the region is Turkey, which conducts a strictly differentiated strategy with regard to the states of the South Caucasus: a clear-cut policy of facilitating Azerbaijan in all spheres; a tactically-motivated friendship and a drive for partnership with Georgia; and a policy of blackmail, isolation, and blockade with regard to Armenia. Turkey regards Armenia not only as a neighbor country having political problems, but also as a wedge interrupting the Turkic East-West ethno-cultural continuum.

Although there are political circles within Armenia that are aiming at establishing a wide-ranging relationship with Turkey, the existence of stable political and diplomatic relations (Armenia tried more than once to establish the latter) remains determined both by the problem of the Armenian genocide in Ottoman Turkey and the ongoing Karabakh conflict. In the sphere of economics, Turkey's presence in Armenia's commodities market appears to be quite sufficient, and further development of relations seems senseless for the Armenian economy. Turkey is a country possessed of neither high technologies nor a developed scientific infrastructure. And a full-scale Turkish penetration into Armenia, even in the realm of the economy, is fraught with danger to Armenian national security.

The regional policy of Iran, the third crucial player in the region, is quite different. Iran's antagonism with the West, particularly with the U.S., its traditional regional competition with Turkey and the latter's activity in the South Caucasus-Central Asia geopolitical space, the renewed territorial claims by newly-independent Azerbaijan with regard to the northwestern provinces of Iran, as well as the need to overcome international isolation all push Iran into rapprochement with Russia and into a recognition of Armenia as a crucial barrier to the expansionist fantasies of Turkey, as well as to a clear danger emanating from Azerbaijan that is seen to be threatening Iran's territorial integrity. In the meantime, while the anti-Iranian political tendencies of Turkey may oftentimes be precarious within the framework of a remote strategy and are thus easily neutralized, for example, by using the Kurdish factor or other regional instruments, the Azerbaijan Republic, through its mere existence, is a permanent hazard for Iran.

It may be appropriate to note that all territorial claims to portions of Iran on 
the part of Azerbaijan, so conspicuously displayed during the presidency of A. Elchibey, have been based upon neither historical, political, cultural, or any other substantiations. The only link of Iran's northern provinces to the population of the Azerbaijan Republic is common language; in all other aspects-outlook, ethno psychology, national consciousness, etc.-Azerbaijan and the northern provinces of Iran are differing ethnic formations. As regards the similarity in the names of the two areas, as noted above, the name of the Transcaucasian Republic of Azerbaijan was invented artificially with a view towards the future annexation of the northern provinces of Iran by the newly emerging Soviet Republic. Armenia is of primary importance in this regard, since it holds Iran's territorial integrity and stability as a cornerstone of its national security, to say nothing of its role as a link to Russia due to their record of friendship and the current state of strategic partnership. The Iran-Russia relationship at the present moment is friendly on the whole, despite some competition and occasional bilateral mistrust, both with historical roots; however, both countries are interested in the betterment of relations. Armenia may yet play an important role in the virtual Moscow-Yerevan-Tehran axis, which has not yet materialized but seems to be gathering momentum.

The relevance of Armenia for Iran is also substantial within other contexts of regional security. As for Armenia itself, due to the above-mentioned factors, it approaches its relations with Iran as a political constant regardless of any potential political developments in the future. Armenia is absolutely unequivocal in claiming that these two countries are connected by a common ancient culture, civilization, communion, etc. A friendly and impartial attitude to Iran is one of the most significant elements of the Armenian national weltanschauung.

The South Caucasus policy of the United States, in contrast to those of Russia, Turkey, and Iran, has no historical tradition, but instead follows definite strategic principles. In this context this primarily means adherence to the model of balances and equilibrium, the desire to establish close relationships with an ever-growing number of parties, and the formation of overlapping alliances in order to create a system facilitating the resolution of regional problems.

It should also be noted that developments in the region-including the Turkish-speaking states of Central Asia-are generating disappointment in the political system of Turkey, the main U.S. ally and its model of economic development in the region. Also basically unclear are the prospects for the strategic development of Russia, Turkey, and Iran: 1) How final is Russia's choice to establish a democratic national state? 2) How stable is the pro-Western orientation of Turkey? 3) What course of liberalization will be taken by Iran, and will it affect that country's system of external political priorities?

Moreover, Turkey may find itself confronted by the issue of inter-ethnic conflicts that threaten the integrity of the state: over 25 percent of its 65 million people are from non-Turkic nations (the Kurds, Zazas, Caucasians, Armenians, Gypsies, Assyrians, etc.). In all, only 40-50 percent of the population is composed of eth- 
nic Turks. Despite the recent diminishment in the Kurdish movement, following the detention of its leader A. Ocalan, the Kurdish problem is certainly the principal internal problem in Turkey, having taken on an increasingly hazardous character. The military option can provide only a temporary reprieve from the stark necessity for radical reforms, with no prospects of eventual resolution. Turkey quite definitely has experience in resolving similar problems; however, it is no longer 1900, and the physical extermination and expulsion of a nation (as was the case with the Armenians) has become extremely difficult to accomplish. Incidentally, added to the Kurdish problem are also national aspirations by the Zazas, an Iranian-speaking ethnic group of nearly five million people inhabiting Central Anatolia, mainly the province of Dersim (now Tunceli). The existence of functioning Zaza political parties, having coherent programs, trained leaders, and military organizations, along with a Zaza movement press, supported by a diaspora community of almost half a million in Western Europe advocating the establishment of an independent Zazistan, can be definitely considered a reality. This movement will no doubt gather momentum, despite the apparent distaste in Kurdish political circles for any independent manifestations of a desire for Zaza national self-determination as well as the attempts of the Turkish authorities to manipulate the whole process, with the purpose of fragmenting the Kurdish movement. There is also a complex situation involving the heterodox Islamic sects (such as the Alevi movement), which have always been the origins of political tension despite the current Turkish policy of naturalizing those trends and using them for disseminating the national ideology.

Still, the disintegration of the Turkish state would seem to be contrary to the interests of Armenia. The establishment of a Kurdish political formation adjoining Armenia, despite detaching the latter from the Turkic concentration on the West, would represent no small threat to Armenia's national security. The putative Kurdish state would most probably be characterized by permanent internal intertribal and factional conflict, armed rebellion, extreme instability and, finally, by an unpredictable foreign policy. This formation would be far from friendly towards Armenia for many reasons, including the fact that the land claims of the presumed Kurdistan are distributed equally across historical Western Armenia (Eastern Anatolia) and Eastern Armenia (the present-day Republic of Armenia and part of the Republic of Azerbaijan). In addition, the ideology of the Kurdish movement is in general extremely expansionistic and belligerent, including in its different versions claims to huge territories from the Persian Gulf to the Black Sea and the Caspian Sea, identifying as Kurdish a great number of small Iranian-speaking ethnic formations like the Lurs, Bakhtiars, Laks, Gurans, and Zazas, as well as branding many cultures that have existed in the region since the time immemorial as Kurdish. The creation of an independent Kurdish state (even outside Turkey)

\footnotetext{
${ }^{2}$ See Iran \& the Caucasus, vol. IV, 397-408.
} 
would become a factor of destabilization for the whole region. It would be a threat to Iran's integrity as well, causing a chain reaction of similar claims among other ethnic formations abundantly present in all the countries of the region.

For the Armenian national interest, it is at all events preferable to be neighbored by a country, like the present-day Turkey, that is hostile but that has the traditions of statehood and functions, at least formally, within internationally recognized legal standards, rather than a virtually ungovernable (and hence unpredictable) Kurdish political formation. A Kurdish state on the doorstep of Armenia would pose a constant threat and hazard, lacking any traditions of regional statehood or commonality and still hostile towards Armenia, even possibly with criminal bias (the examples of Chechnya, the Taliban regime in Afghanistan, and, the so-called Kurdish Sector in Northern Iraq that emerged after the Persian Gulf War).

Turkey, despite its military might, is rather a vulnerable construct, with quite a lot of hard times ahead. Whether it is able to resolve the Kurdish conflict and other no less important issues (like recognizing the genocide of the Armenians and undoing its effects) will largely determine its relevance as a major regional factor.

In this connection it should be noted that a similar approach to analyzing the ethnic situation in Iran and its prospective development would be both incorrect in principle and methodologically unsubstantiated. Iran is an ancient nation, having a nearly three-millennia-long tradition of uninterrupted statehood. It is a country that integrates the nations that have always been part of the historical Iran and have clearly recognized their Iranian affiliation, which applies to all nations populating Iran, including those of non-Iranian origin. Within its currently existing borders, Iran is a completely natural formation-not a single part of it has ever been annexed to its territory artificially (by force). Not a single nation or ethnic group currently inhabiting Iran has ever been annexed to Iran along with its ethnic territory; all of them had either originally resided on Iran's territory, or had moved to Iran from other locations. That has resulted, despite ethnic diversity and the persistence of unique traditions of different groups, in a shared mentality or concept of the common Iranian idea. Therefore, the separatist ideas presented in their various forms in Iran have no historical basis, often being imported from outside the country by foreign stakeholders or political movements. In this respect, it is also highly symptomatic that the pan-Iranian idea itself as a cultural movement has originated in the Turkic-speaking areas of Iran, namely Aturpatakan (Azerbaijan), most of its leaders being natives of the North Iranian provinces, mainly Tabriz (Ahmad Kasravi-ye Tabrizi, Yahya Zoka, etc.).

Nothing of the kind can be said about the peoples comprising the Ottoman Empire or Turkey. For the ethnic groups resident in Turkey, the concept of Turkish statehood has often been associated with invasion of their historical territories, despotic rule, a repressive state machinery targeted primarily against the non- 


\section{THE QUARTERLY JOURNAL}

Turkic ethnic groups which had never identified themselves with the Turkish state and were often alienated from the very idea of statehood itself.

No analysis of the regional situation or its prospective development is possible today without considering China, the Giant of the East. The Chinese stakes in the South Caucasus are not so explicit as those of Russia, the U.S., Iran, or Turkey. This does not mean that the Chinese stakes are absent, but that they will have to emerge yet more distinctly hereafter. Moreover, within the given context Armenia is posing as a factor effectively countering the Turkic element and the pan-Turkic political objectives, a fact that is quite relevant for China with regard to the Uighur problem in the Xinjiang region.

That is also corroborated by the current Sino-Russian rapprochement in Central Asia, which is driven by the Russian intention to retain its strategic control over Central Asia and by the Chinese concern for the potential menace of Uighur secessionist tendencies as well as by the increasing prevalence of Islamic fundamentalism in Central Asia. A stable Central Asia will in turn enable China, given reliable support, to expand along East Asian and South Asian strategic lines, a development which has met with some success to date. It may be assumed that the growth of anti-Chinese nationalism in Xinjiang will prod China to more vigorous action in the region aimed at boosting the Armenian factor and counterbalancing the political forces in Transcaucasia.

The European Union, in its turn, being concerned with issues of East European security closely linked to possible developments in Russia, as yet has refrained from action within its zone of military and political influence and will most likely remain for the time being in its role as protector of the shared Western and European economic interests.

Thus, being a complicated ongoing process, the establishment of the new world order will hardly proceed with no major disturbances, since what we see in this example is an unprecedented displacement of world forces. Much depends in particular upon the current deployment of relationships between the U.S. and Russia, and on their prospective development. The South Caucasus is distinguished by intense ethnic friction; an important element of these frictions lies in deeply rooted historical problems, which means that the region remains a high security risk.

Let us now address Armenia itself, which has achieved several extremely important landmarks within the last decade of the century, particularly its newly acquired independence. In the meantime, a highly dynamic external environment (the Karabakh problem in particular) was accompanied by the stagnation of internal development - sort of a political timelessness - the sole indicator of dynamism being unfortunately the data on migration of the population. The primary cause of this displacement was the seizure of power after independence by political forces that not only disregarded Armenia's best situation vis-à-vis its region in history, but rather pursued policies whereby the needs of the Armenian nation as 
a stakeholder were replaced by the personal ambitions of a small group in power. The unambiguous priority of personal interests, a predatory attitude toward the national assets, the all-round looting of national wealth, including the legacy of the Empire, continually inept staff selection, and opaque power structures, along with a number of other negative factors fostered by the new politicians, resulted in a high degree of social frustration that was the prime cause of migration. These conditions were exacerbated by the fact that they took place against the background of a decade-long blockade, the energy crisis of the mid-90s, a continuous economic slump, political tension around Armenia related to the Karabakh war, and the failure of any positive tendencies to appear. The only viable structure of post-Soviet Armenia was probably the Armenian Army, which had already proved its combat readiness in the Karabakh war. It can be definitely asserted that, as of today, the Armenian Army is the best trained army in the Transcaucasian region, highly committed to and targeted at the fulfillment of the many Armenian national aspirations that have, as it were, piled up throughout the centuries. It is, however, to be admitted that success in this sphere has been possible in contravention of rather than due to the existing political order in the country. That success exacted an enormous cost from the entire population of Armenia, which stoically suffered the hardships of the general social crisis, which was often explained away by the existence of the Karabakh conflict.

One thing is sure: given the complexity of the problems confronting Armenia at the dawn of independence, there were also a number of unambiguously positive factors which could have been leveraged efficiently to upgrade the country to a new level of development. We are looking here not only at the economic or scientific potential, which are quite substantial for a small regional country, but at the objective and positive reality.

Armenia is one of the important geopolitical factors in the region, one that is quite invulnerable to possible targeted impacts from the outside. In contrast to the multinational formations of Georgia or Azerbaijan, Armenia is essentially a mono-ethnic state having no internal problems with ethnic minorities. In fact, it is the only country in the wider region having its primary ethnic population in a concentration in excess of 95 percent. The most significant national minority in Armenia are the Yezidis (an ethno-confessional Kurdish-speaking group), numbering slightly over 52,000 according to the 1989 census. It is true that, at the start of independence in the 1990s, certain external parties attempted to convince the Yezidis of their identity with the Kurds, in order to involve this community in the Kurdish political movement. Those attempts, however, can in no way be termed successful, for they were coincidental with the peak of the Yezidis' emerging national consciousness that had been denied throughout the decades of Soviet power. The Yezidis retained their unity and unambiguously dissociated themselves from the Kurds. These attempts were doomed to failure, given the history of the Yezidis as a separate ethno-religious group having inherent features 


\section{THE QUARTERLY JOURNAL}

qualitatively differentiating them from the Kurds. The purpose of the artificial initiation of the so-called "Kurdish" minority in Armenia, failing a more convenient handle for political manipulation, was, of course, to draw Armenia into the orbit of states having a "Kurdish factor," with all the relevant implications. (Clearly, even a complete Kurdization of the 50,000 Yezidis could hardly constitute a contribution to the multi-million-strong Kurdish movement; however, a minority of 50,000 in a country of three million could easily be transferred into a basis for creating the abovementioned instability.)

Armenia is unitary not only ethnically and confessionally, but also in many social and clanship features that could otherwise initiate undesirable political developments in the country. In contrast, the title ethnic group of Azerbaijan (the basic Turkic-speaking population of the country) is a rather heterogeneous mass with different components having divergent aspirations, to say nothing of the minorities: the Talishis, the Lesgians, the Kurds, and the Tats. Georgia, too, shows heterogeneity in the title ethnic formation itself, though of a type differing from that of Azerbaijan; the concept of "the Georgians" is inclusive of actually diverse ethnic formations, including the Georgians proper, the Svans, the Mingrels, and the Adjarians, with many local variations and specific life styles. All those things generate local interests threading through the entire system of power, thus weakening and compromising the country's national security. Armenia, too, has clans, but these are very dynamic (often changing and short-lived); in addition, the people who join these clans exclusively have common economic and political interests, regardless of their origin, family, social grouping, etc.

Moreover, among the countries of Transcaucasia, Armenia is distinguished by the all-embracing ideas of national belonging, Armenian statehood, and common spiritual heritage, all of which facilitate interior stability under any conditions, as was clearly shown in the recent years of deep economic and political crisis. This unifying quality is certainly rooted in the historical past of the Armenians: the loss of their ethnic territories, suffering genocide and exile, having a large diaspora community. The idea of a "common house" for the Armenian nation has become a part of the national mentality, an element of both national mind and world outlook.

At the same time, it should be noted that the weak point of Armenia compared to its neighboring countries is its low demographic indications, with a high rate of emigration and low population density in the bordering areas. Despite the previous ten years of Armenia's independent existence, one of the principal issues that still remains to be resolved is developing a carefully calculated and scientifically developed geo-strategic line of conduct and elaboration of its national security conception. 